Christopher J. Neely is a senior economist at the Federal Reserve Bank of St. Louis. Mrinalini Lhila provided research assistance. The author wishes to thank Mathias Zurlinden of the Swiss National Bank for assistance obtaining the Swiss intervention data, Owen Humpage of the Federal Reserve Bank of Cleveland, and Doctors Esswein and Schaub of the Deutsche Bundesbank for assistance obtaining the German data.

\section{Are Changes in Foreign Exchange Reserves Well Correlated with Official Intervention?}

\section{Christopher J. Neely}

ince the advent of the floating exchange rate Sera in 1973, economists and policymakers have been forced to cope with unexpected volatility in exchange rates. Such volatility can complicate the achievement of price stability and have undesirable effects on output and employment-especially in small, open economies. To counteract troublesome currency fluctuations, central banks often intervene in foreign exchange markets-buying and selling their own currency to influence its value. ${ }^{1}$ Such intervention raises a number of questions: How frequently do central banks intervene, and what conditions prompt them to do so? What are the goals of intervention? Does intervention influence the exchange rate? Is intervention profitable for central banks? Answering such important questions is difficult because central banks traditionally have been reluctant to release intervention data to researchers, considering it to be too sensitive. The lack of actual intervention data has been a major handicap to the literature on intervention (Edison, 1993).

Researchers have pursued several strategies to address the lack of data. Some researchers have obtained and examined intervention data after agreeing to keep details of specific transactions confidential (Loopesko, 1984; Mastropasqua, Micossi, and Rinaldi, 1988; Humpage, 1999). Others-e.g., Peiers, 1997; Goodhart and Hesse, 1993-have used news reports of intervention to substitute for actual intervention data. ${ }^{2}$ A very popular strategy has been to use publicly available foreign exchange reserves data to proxy for unobservable intervention data. International reserves are assets that can be used directly for settlement of international debts, payments to foreign countries. Such assets include securities, bank deposits, gold, special drawing rights (SDRs), and reserve positions in the International Monetary Fund (IMF). Foreign exchange reserves are those international reserves-typically securities or bank deposits-denominated in a foreign currency, rather than gold or SDRs. ${ }^{3}$

Using changes in reserves to proxy for intervention has permitted researchers to study intervention in a much wider variety of countries and over longer time spans than would a strategy of using only actual intervention data. Taylor (1982b), for example, estimated the profitability of intervention for a multicountry data set using reserve changes-modified for SDR allocations, reserve revaluations, and other factors-as a proxy for intervention. A series of studies-Obstfeld, 1983; Kearney and Macdonald, 1986; Gartner, 1987 and 1991 - have used changes in reserves to estimate official intervention reaction functions. Several papers have used reserves data to examine the extent to which intervention is sterilized or whether it signals monetary policy (e.g., Takagi, 1991; Neumann and von Hagen, 1993). Almekinders (1996) examined the relationship between central bank independence and intervention activity. Finally, Szakmary and Mathur (1997) used reserves data to investigate the relationship between technical trading rule returns and intervention for a cross section of countries.

The problem with these studies is that reserves are an imperfect proxy for official intervention. Reserves will change not only when central banks conduct foreign exchange intervention operations but also for other reasons, for instance, a government payment of debt denominated in a foreign currency. The question to be addressed here is:

\footnotetext{
${ }^{1}$ Most research on intervention uses the term intervention to refer to sterilized intervention, which is defined in the first boxed insert.

${ }^{2}$ Klein (1993) finds that for U.S. intervention from 1985-89, 72 percent of interventions were reported by the Wall Street Journal and that 88 percent of reports were correct.

${ }^{3}$ Potential claims that could be created through swap lines or lines of credit do not constitute reserves.
} 
How well are changes in foreign exchange reserves correlated with official intervention? ${ }^{4}$

To answer this question, we compare U.S., Swiss, and German intervention series with measures derived from reserves data using time series graphs, correlations, seasonal adjustment, and other statistical procedures. We consider whether any simple adjustments can make reserves better proxies for intervention. We must be circumspect in our conclusions, however, as the three cases we use may not be representative of the relationship between foreign exchange reserves and intervention in other countries-or, over other time spans.

The next two sections of this article will describe briefly the motives for holding international reserves and for intervening in currency markets. The fourth section considers reasons why changes in reserves may not correspond perfectly to intervention. The fifth section compares changes in foreign exchange reserves to intervention data for the United States, Germany, and Switzerland using time series statistics, rolling and static correlations. The final section draws conclusions and suggests avenues for further research.

\section{WHY DO COUNTRIES HOLD INTERNA- TIONAL RESERVES?}

The traditional purposes for holding

international reserves have been to:

1) Directly finance international payments imbalances;

2) Intervene in financial markets to provide liquidity in times of crisis; and

3) Influence the exchange rate.

Reserves-which are typically held in the form of short-term, highly liquid, interest-bearing securities - also can be used to pay for ordinary government purchases from abroad or to repay debts denominated in foreign currency. The first boxed insert discusses the size and composition of reserves over time.

A large literature on the demand for reserves has estimated the theoretical benefits and costs of holding reserves and has compared those predictions to actual reserve holdings (Grubel, 1971; Lizondo and Mathieson, 1987; Ben-Bassat and Gottlieb, 1992b). Under a fixed exchange rate system, such as the Bretton-Woods system, the primary benefit of holding reserves is to permit the authorities to directly finance a balance of payments deficit rather than pursuing undesirable macroeconomic or exchange rate policies in the face of external pressures. Therefore, factors that make imbalances in international payments larger or more variablelike a higher volume of trade or more variable trade and/or more variable international investment or net factor income payments-increase the likelihood of benefiting from holding reserves and tend to raise the desired level of reserves. Even under floating rate systems - which constrain policy less than fixed-rate systems-policymakers often value the options that holding reserves gives them.

The opportunity cost of holding reserves is the foregone investment because resources have been used to purchase reserves instead of increasing domestic capital. Thus, the marginal product of domestic capital is the opportunity cost of holding reserves. Often the marginal product of capital is measured as the domestic interest rate. Because of information asymmetries, however, international investment generally will be below the full-information level and the marginal product of capital will exceed the cost of funds in the global market (BenBassat and Gottlieb, 1992a). Therefore, the domestic interest rate probably is a lower bound on the opportunity cost of holding reserves. Consequently, the literature explains the demand for international reserves as a tradeoff between the benefits of greater policy freedom and the costs of holding reserves, i.e., the difference in return between domestic and foreign investment.

\section{FOREIGN EXCHANGE INTERVENTION}

The term foreign exchange intervention usually describes sterilized intervention, which is explained in the second boxed insert. Several purposes for intervention have been suggested. First, many researchers have found evidence for "leaning-againstthe-wind" intervention. This has been defined var-

\footnotetext{
${ }^{4}$ One previous study has considered this question. Mastropasqua, Micossi, and Rinaldi (1988) evaluated the relationship of confidential European Monetary System intervention data for Belgium, France, Germany, and Italy to reserve-based estimates of intervention and the monetary base. Despite considering a different group of countries in a target-zone exchange rate regime and a different sample period, they estimated correlations that are not much different than those presented in this article: Interventions and reserve changes are loosely related. Mastropasqua, Micossi, and Rinaldi (1988) did not, however, examine the reasons why changes in reserves might differ from intervention or how to improve those measures.
} 


\section{THE SIZE AND COMPOSITION OF INTERNATIONAL RESERVES}

\section{Holdings and Currency Composition of Foreign Exchange Reserves}
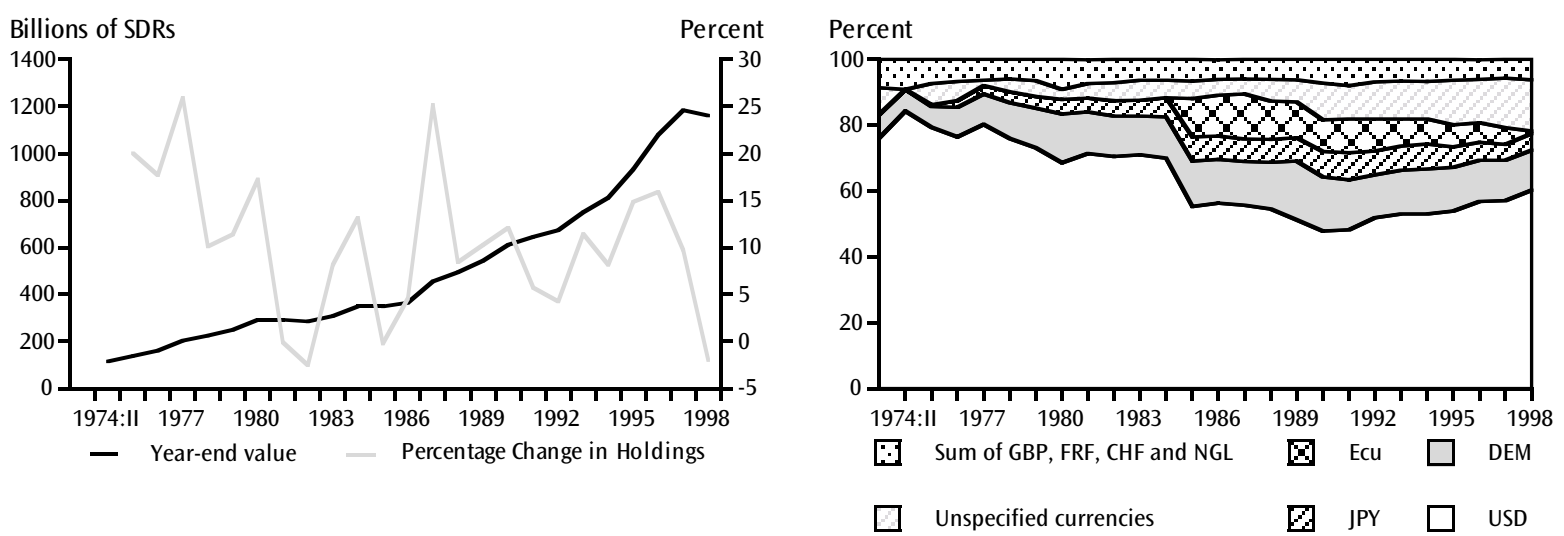

Notes: The left panel shows the holdings and changes in foreign exchange reserves. The right panel shows the currency composition of those reserves. The codes GBP, FRF, CHF and NGL stand for the British pound, the French franc, the Swiss franc and the Dutch guilder, respectively.

There have been two unfulfilled predictions about the size and composition of international reserves. First, at the end of the Bretton-Woods era of fixed exchange rates in 1973, it was widely expected that countries would cease to hold substantial international reserves. The major purpose of reserves had been to intervene in support of the Bretton-Woods exchange rate pegs. If exchange rates were to be allowed to float, there didn't seem to be much point in holding substantial reserves (Batten, 1982). Time has proven this prediction wrong. The left panel of the figure shows that the total official end-of-year holdings of foreign exchange reserves-left-hand scale-as reported by the IMF, has been increasing fairly steadily since 1970 . Its percentage rate of increase - right-hand scaletailed off in 1992 and 1998, presumably as a result of intervention during the European Exchange Rate Mechanism (ERM) and Asian crises, respectively.

The second unfulfilled prediction is the imminent downfall of the U.S. dollar as a dominant reserve currency (see The Economist, 1994, or Roberts, 1995). Central banks choose the currency composition of their international reserves on many of the same grounds as other investors. They seek to minimize risk for a given rate of return on a portfolio of highly liquid assets. In practice, this means that reserve currencies typically are held because their assets are considered relatively safe from political risk and are expected to be subject to relatively low and stable inflation. Since at least the Bretton-Woods conference of 1944 , the U.S. dollar has been the predominant international reserve currency, succeeding the British pound in the role. The relative soundness of U.S. political institutions and lack of regulation of U.S. financial markets have helped boost demand for the dollar as a reserve currency.

Several factors have led analysts to predict the downfall of the dollar as a dominant reserve currency. First, the large external, dollar-denominated U.S. debt creates an incentive for the United States to reduce the real value of this debt with inflation and may reduce the confidence of international investors in the dollar (The Economist, 1994). Second, some analysts predicted the decline of the dollar as a result of imprudent economic policy, including high inflation, large trade deficits, and a resulting weakness in the international value of the dollar (Roberts, 1995). Finally, international efforts to liberalize financial systems will inevitably weaken the dollar as a reserve currency by increas- 
Continued from previous page.

ing the relative attractiveness of holding assets in other currencies. ${ }^{1}$

The right panel of the figure shows that-after a long decline - the role of the dollar as a reserve currency actually has grown over the past decade. The U.S. dollar has maintained and even increased its importance as a reserve currency, though the figures are sensitive to fluctuations in exchange rates. Barring irresponsible U.S. economic policy, any reduction in the importance of the U.S. dollar as a reserve currency is likely to happen only gradually.

What are the consequences if the dollar ceases to be a reserve currency? The only tangible advantage to being a reserve currency-as opposed to having the dollar used internationally - is that demand for dollar-denominated securities may permit the United States to borrow from abroad at slightly lower interest rates than otherwise would be possible. This official demand for U.S. assets should widen the spread between U.S. government and private bonds. Blinder (1996), however, reports that the U.S. spread is no larger than that of other countries. In other words, the spread does not show that the dollar's role as an international currency has lowered the U.S. Treasury's borrowing costs. In addition, the U.S. spread has widened slightly in recent years, indicating that any reduction in borrowing costs is not diminishing. It is not clear that Blinder's argument is correct, however. If government and private bonds are (imperfect) substitutes for some investors - even if not for foreign central banks - arbitrage by those investors would keep the interest rates on U.S. government and private bonds reasonably close.

While the advantages to having one's currency used as a reserve currency are modest, so are the disadvantages. The chief disadvantage to having one's currency used as a reserve currency is that shifts in international portfolios can destabilize the domestic economy. The size of the U.S. economy mitigates these effects, however.

\footnotetext{
${ }^{1}$ Despair about the dollar's role as an international currency has not been universal; see Frankel (1995) for example.
}

iously as intervention that counters short-term market trends-buying dollars as the dollar depreciates (Taylor, 1982b), for example-or intervention that is inconsistent with current or future fundamentals - buying dollars despite expectations of lower U.S. interest rates in the future (Lewis, 1995; Kaminsky and Lewis, 1996), for example. Second, intervention may be used to remedy "misalignments" or exchange rates that are inconsistent with purchasing power parity considerations (Gartner, 1987 and 1991; Neely, 1998). Edison (1993) reports almost universal and strong support for leaning-againstthe-wind intervention by monetary authorities but relates less support for the idea that authorities intervene to correct misalignments.

Although the U.S. Treasury has primary responsibility for U.S. exchange rate policy, the Federal Reserve and the Treasury generally collaborate on foreign exchange intervention decisions, and the Federal Reserve Bank of New York conducts operations on behalf of both. The purpose of U.S. intervention, as set out in the Foreign Currency Directive, is to "counter disorderly market conditions." The concept of "disorderly market conditions" is not precisely defined, but often has been interpreted as including periods of high volatility or abrupt changes in exchange rates. Intervention is conducted in a manner consistent with the IMF Article IV, Section 1, which forbids attempts to remedy balance of payments problems by manipulating exchange rates, and is often undertaken in cooperation with foreign central banks. ${ }^{5}$

Central banks are notoriously reluctant to release data on their intervention operations. The Federal Reserve, along with the Treasury of the United States, has been an exception to this rule, releasing daily intervention data with a one-year lag. The Federal Reserve publishes data in the Federal Reserve Bulletin on reserves valuation changes and profits/losses on intervention. ${ }^{6}$ Why do most

\footnotetext{
${ }^{5}$ The Foreign Currency Directive outlines the reasons for Federal Reserve foreign currency transactions. It is published annually in both the Federal Reserve Annual Report and in the Federal Reserve Bulletin along with the minutes of the first Federal Open Market Committee meeting of the year.

${ }^{6}$ Changes in U.S. foreign exchange reserves also are reflected in the "other" asset category on the consolidated statement of all Federal Reserve Banks published each Thursday in the H.4.1 statistical release.
} 


\section{STERILIZED INTERVENTION}

\section{Stylized Balance Sheet of the U.S. Monetary Authorities}

\begin{tabular}{llll}
\multicolumn{1}{c}{ Assets } & \multicolumn{2}{c}{ Liabilities } \\
\hline Foreign exchange reserves & $+\$ 100$ million $(1)$ & $\begin{array}{l}\text { Currency plus deposits held } \\
\text { with the Federal Reserve }\end{array}$ & $+\$ 100$ million $(1)$ \\
& & & \\
U.S. government securities & $-\$ 100$ million $(2)$ &
\end{tabular}

Because exchange rates are important prices that influence the time path of inflation and output, central banks often intervene in the foreign exchange market, buying and selling currency to influence exchange rates. Such intervention typically is sterilized, meaning that the central bank reverses the effects of the foreign exchange transactions on the monetary base. ${ }^{1}$ For example, if the Federal Reserve Bank of New Yorkfollowing the instructions of the Treasury and the Federal Open Market Committee - purchased $\$ 100$ million worth of euros, the U.S. monetary base-composed of U.S. currency in circulation plus deposits of depository institutions at the Federal Reserve Banks-would increase by $\$ 100$ million in the absence of sterilization. This transaction is illustrated in the stylized balance sheet items marked as (1). To prevent changes in domestic interest rates and prices, the Federal Reserve Bank of New York also would sell \$100 million worth of government securities-sterilizing the intervention by reducing deposits with the Federal Reserve - to absorb the liquidity. This transaction is marked as (2) in the balance sheet.

To prevent euro-denominated short-term interest rates from rising, the European Central Bank would have to conduct similar open market purchases of euro-denominated securities to increase its money stock to completely sterilize the original transaction. The final net effect of such a sterilized intervention would be to increase the relative supply of U.S. government securities versus euro-denominated securities on the market.

Because sterilized intervention does not affect the U.S. monetary base or interest rates, it cannot influence the exchange rate through price or interest rate channels. It might, however, affect the exchange rate through the portfolio balance channel and/or the signaling channel. The reasoning behind the portfolio balance channel is that if foreign and domestic bonds are imperfect substitutes, investors must be compensated with a higher expected return to hold the relatively more numerous bonds. In the example in which the Federal Reserve purchases euros/sells dollars (USD), the intervention must result in an immediate depreciation of the dollar that creates expectations of future appreciation, increasing the expected future return to dollar-denominated assets and convincing investors to hold the greater quantity of them. The signaling channel, on the other hand, suggests that official intervention communicates to the market information about future monetary policy or the long-run equilibrium value of the exchange rate. A purchase of euros/sale of dollars may signal to the markets that the central bank considers the dollar's current value to be too high given current and expected future policy. The consensus of the research on sterilized intervention is that any influence intervention has on the exchange rate is weak and temporary. ${ }^{2}$

\footnotetext{
${ }^{1}$ Unsterilized intervention is equivalent to domestic monetary policy and therefore is often implicitly excluded from discussions of the efficacy of intervention.

${ }^{2}$ Humpage (1999) provides some evidence that U.S. intervention may influence dollar exchange rates.
}

possibility that central banks are reluctant to release such information because they are trying to avoid accountability. Finally, it is possible that secret interventions - or at least concealing the size of intervention-may make the transaction more effective in influencing the exchange rate in certain circum-

stances (Bhattacharya and Weller, 1997). central banks keep interventions secret? Taylor (1982a and 1982b) suggests that the practice dates back to the Bretton-Woods era of fixed exchange rates, when reports of intervention could trigger a run on the currency. Given that the practice has persisted for more than 25 years after the end of fixed exchange rates, one also must consider the 


\section{WHY DO CHANGES IN FOREIGN EXCHANGE RESERVES DIFFER FROM INTERVENTION?}

Changes in reserves may not correspond to intervention for a number of reasons. First, the dollar value of foreign exchange reserves will be subject to changes in valuation from three sources: changes in the foreign exchange value of dollar, interest income, or coupon payments, and changes in the value of the underlying asset. For example, if the Bank of Canada holds a yen-denominated bond worth C\$1 million, the value of that bond will rise if the yen appreciates against the Canadian dollar or if Japanese interest rates fall, hiking the yen price of the bond.

Second, reserves often are used for transactions other than intervention. Ordinary government purchases from abroad, or the payment of foreign currencydenominated debt, can change reserves, but are not intervention. The United States, for example, issued debt denominated in Swiss francs before the first devaluation of the dollar in 1971 (Taylor, 1982a). When payments were made on this debt, they had to be made in Swiss francs, which could have come from the foreign exchange reserves of the United States.

Third, intervention may be disguised deliberately so that it will not appear in reserve changes. Taylor (1982a and 1982b) reports that France, Italy, Spain, and the United Kingdom hid intervention during the 1970 s by having nationalized industries conduct some transactions. ${ }^{7}$ Japan and France are reported to have intervened with "hidden reserves"-of the authorities-held at commercial banks. France and Italy effectively intervened by regulating the foreign exchange portfolios of (mostly publicly held) commercial banks.

Finally, there are any number of unusual transactions that might cause reserves to change without corresponding foreign exchange intervention. For example, the IMF might allocate SDRs to a country, which would increase its international reserves. Or, assets may be transferred from the official foreign reserves accounts to another government entity. Moreover, intervention will not show up in changes in reserves at all if it is conducted through the forward market and offset with a spot transaction when the forward contract is executed. ${ }^{8}$ These problems complicate the attempt to equate changes in reserves with intervention.

\section{COMPARING CHANGES IN RESERVES TO INTERVENTION}

To the extent that changes in reserves lead to the same answer to the particular question under investigation, reserves are a useful proxy for intervention. While we cannot replicate every study using reserves to proxy for intervention, we can compare characteristics of the series to see in what respects they are similar. For example, one might hope that the series would be highly correlated and would share similar autocorrelation functions.

\section{The Data}

We will use three samples of known intervention data:

1) U.S. daily intervention and monthly reserves data from 1973:04 to $1998: 12$;

2) Swiss daily intervention and monthly reserves data from 1986:01 to 1995:12; and

3) Bundesbank daily intervention in dollar markets and monthly reserves data from 1976:01 to $1996: 10$.

In each case, the daily intervention data were cumulated over calendar months to facilitate comparison with monthly changes in reserves.

The intervention series for the United States includes both in-market and with-customer transactions. In-market transactions are intended to influence the exchange rate, while with-customer interventions are transactions with other government entities that also change the relative supplies of domestic and foreign bonds-like a payment to a foreign government in foreign currency. ${ }^{9}$ The intervention series for the Swiss National Bank includes Swiss franc (CHF) purchases of U.S. dollars (USD) and deutschemarks (DEM). The German intervention figures include only interventions in the USD (non-EMS) market. All intervention figures show

\footnotetext{
${ }^{7}$ If a nationalized industry changes the mix of domestic and foreign bonds that it either issues and/or holds in its portfolio, this will change the relative supplies of such bonds available to the rest of the world, just as a sterilized intervention would.

${ }^{8}$ Consider the following intervention through the forward market: 1) U.S. authorities purchase dollars forward. 2) At the expiration of the forward contract, the U.S. authorities simultaneously sell dollars in the spot market and purchase them under the forward contract. During the duration of the forward contract, the intervention would tend to support the dollar, but U.S. reserves would never change.

${ }^{9}$ The United States conducts most intervention in the DEM and JPY, although other currencies have been used. Neely and Weller (2000) discuss the changing nature of intervention over time. Adams and Henderson (1983) and Humpage (1994) provide more information on the institutional details of U.S. intervention.
} 
purchases of foreign exchange in millions of U.S. dollars. Note that in a coordinated intervention to purchase dollars, U.S. intervention would be recorded as a negative number - a sale of foreign exchangewhile German and Swiss intervention would be recorded as a positive number. ${ }^{10}$

The foreign exchange reserves series for each country were obtained from the IMF through Haver Analytics. The IMF obtained the figures from the national authorities. The reserves series are in millions of dollars.

The top panel of Figure 1 illustrates the intervention series-cumulated over months-provided by the central bank of each country, with the corresponding changes in the foreign exchange reserves series in the bottom panel. For each country, the changes in reserves appear to be far more variable than the monthly intervention series, confirming that intervention is not the only reason for changes in reserves.

Table 1 shows summary statistics on the series; the reserve series have far larger standard deviations and mean absolute changes. For example, the standard deviation of U.S. intervention is $\$ 860$ million while that of the change in U.S. foreign exchange reserves is $\$ 1,275$ million. The mean absolute change for each of those series is $\$ 355$ million and $\$ 741$ million, respectively. The intervention series are all autocorrelated positively at the first four lags. The U.S. reserves series has smaller positive autocorrelation at the first four lags - ranging from 0.477 to 0.162 - while the German and Swiss reserves series are actually negatively autocorrelated at lags one and two.

\section{Correlations Between Intervention and Changes in Reserves}

Despite the greater volatility of the changes in reserves, such a series might be a useful proxy for intervention-depending on the application-if it is correlated with intervention. The third column of Table 2 (labeled $\rho$ ) shows the correlations between the measures over subsamples. ${ }^{11}$ The unconditional correlations of the central bank intervention with changes in foreign exchange reserves are modest, equaling 0.423 for the United States, 0.192 for Germany, and 0.123 for Switzerland.

Correlations can change over time, however. To investigate the stability of this correlation over time, we can compute a four-year rolling correlation between central bank intervention and changes in foreign exchange reserves. Figure 2 displays the backward-looking series of correlations from this exercise. Each of the time series of rolling correlations shows relatively high correlations through the 1980 s that fall off sharply during the early 1990s.

Why do the correlations fall off during the 1990s? Figure 3, which displays the product of the interventions and changes in reserves, sheds some light on this question. For each country, there was heavy intervention during 1987-89-the period following the 1987 Louvre Accords - that also was reflected in changes in reserves, resulting in high correlation during that period. The falloff during the 1990s seems to mostly reflect a lack of intervention during the early-to mid-1990s (see the upper panel of Figure 1), rather than a period of mixed correlation with changes in reserves. By the mid1990s, the heavy interventions of 1987-90 were no longer included in the data window over which the rolling correlations were computed. In the case of the United States, this instability in intervention strategy reflects the fact that intervention is generally a political decision of the President and the Secretary of the Treasury. Intervention was rare, for example, during the first Reagan administration from 1981-84 and during the Clinton administration after 1993.

\section{Omitting ERM Crises}

Recall that the German data only include intervention in dollar markets; they exclude intra-Exchange Rate Mechanism (ERM) intervention. Substantial changes in reserves as a result of intervention to support the ERM may be related negatively to the dollar intervention series. This suggests an investigation is warranted of the German correlation after excluding months of ERM realignments for major currencies. The months of ERM entrances, realignments, or exits for the French franc (FRF), the Italian lira (ITL), the Dutch guilder (NGL) and the British pound (GBP) are 1979:09, 1981:03, 1981:10, 1982:06, 1983:03, 1985:07, 1986:04, 1987:01, 1990:01,

\footnotetext{
${ }^{10}$ Results with other measures of intervention activity also were computed for the United States and Switzerland. In addition, results were computed for each case with a broader measure of reserves, total reserves minus gold. Those results will be omitted for the sake of brevity, but were similar to those presented here. The full set of results is available from the author upon request.

${ }^{11}$ The standard errors in Table 2 are those implied by the first-order bivariate vector autoregressive representation of the pairs of series.
} 

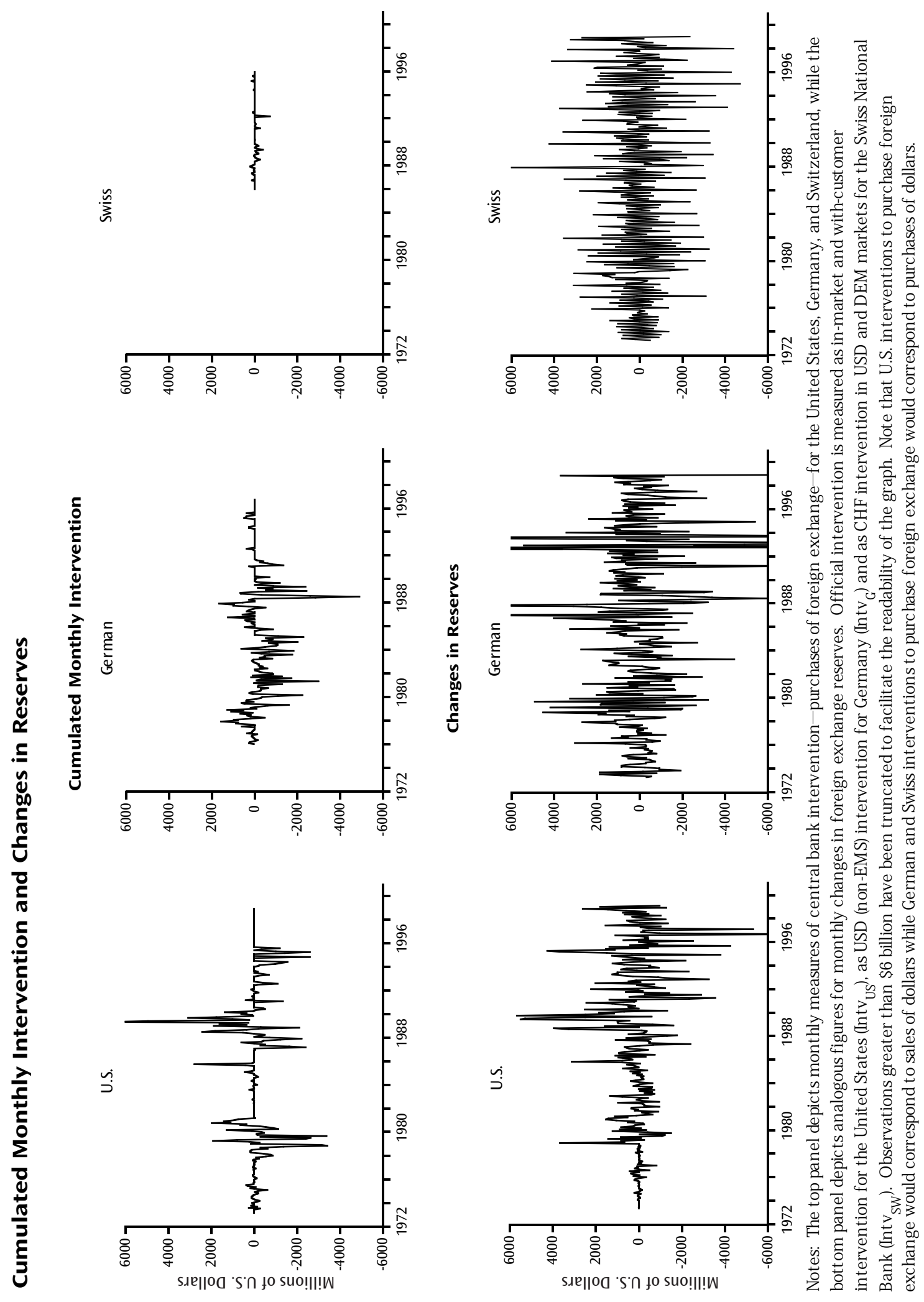
1992:09, and 1993:08. The fourth column of Table 2 (labeled $\rho_{\text {EMS }}$ ) displays the correlation results with these months deleted. Unsurprisingly, the correlation between German dollar interventions and changes in reserves increases from 0.192 to 0.264 . The corresponding correlation for Switzerland rises much more modestly, from 0.123 to 0.132 . Figure 4 compares the time series of rolling correlations for the German data with and without the realignments. The rolling correlations for the German case still fall off sharply in the 1990s, even with the realignment months removed.

Whether the ERM crises are included or omitted, the correlation between changes in German reserves and intervention remains modest over the whole sample. One reason for this might be that foreign exchange swap transactions frequently have been used to conduct monetary policy (Batten et al, 1990). For example, the Bundesbank sold "Bundesbank Treasury discount paper" to foreign investors beginning in March 1993 (Deutsche Bundesbank Annual Report, 1993).

\section{Deseasonalizing Changes in Reserves}

The bottom rightmost panel of Figure 1 appears to show that changes in Swiss reserves have a seasonal component. It also is possible that U.S. and German reserve changes have a subtler seasonal component. This might potentially be of interest since it is very unlikely that central bank intervention has a seasonal element and filtering out the seasonal pattern in reserves might produce a better-more highly correlated-proxy for central bank intervention. To investigate this possibility, we regress changes in reserves on a set of indicator variables spanning the months of the year. While there is no evidence of seasonality for the German and United States reserves, there is overwhelming evidence that Swiss reserve changes have a seasonal component. This is because the Swiss National Bank accommodates a seasonal component in money demand-smoothing interest rates over the course of a year, as does the Federal Reserve-and conducts these monetary policy operations with foreign exchange reserves. ${ }^{12}$ Gartner (1987) notes this seasonality and attributes it to the desire of banks and financial institutions to hold a greater quantity of Swiss francs in their portfolios at the end of quarters. While it is not clear that Gartner's explanation remains valid for recent years, Table 3 shows that it is consistent with the overall behavior of the sample.

\section{Figure 2}

\section{Four-Year Rolling Correlations Between Official Intervention and Changes in Reserves}

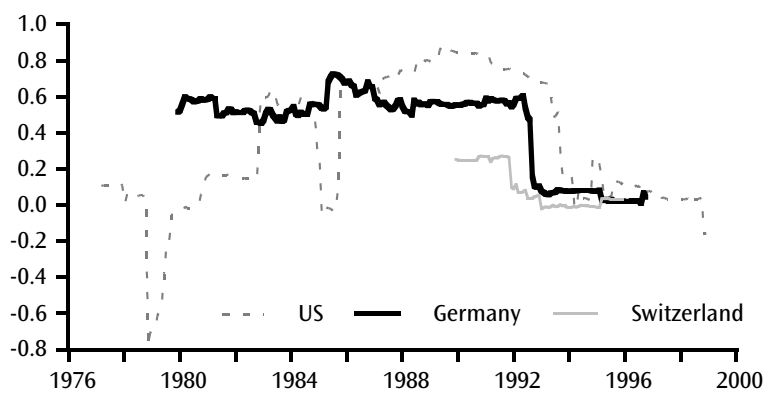

Notes: Official intervention is measured as in-market and withcustomer intervention for the United States ( $\left(\operatorname{ntv}_{\mathrm{uS}}\right)$ as CHF intervention in USD and DEM markets for the Swiss National Bank (Intv ${ }_{S W}$ ) and as USD (non-EMS) intervention for Germany $\left(\right.$ Intv $\left.{ }_{\mathrm{G}}\right)$. Reserves are measured as the dollar value of foreign exchange reserves in each case.

The largest and most statistically significant positive coefficients occur at the end of the financial quarters in March, June, September, and December. The months following these end-of-quarter months show large negative coefficients. In other words, the Swiss National Bank responds to seasonal fluctuations by buying foreign currency/selling Swiss francs during March, June, September, and December and selling foreign currency in the following month.

The fifth column of Table 2 (labeled $\rho_{\text {Season }}$ ) shows that the deseasonalized changes in Swiss reserves exhibit higher correlation with intervention data- 0.215 versus 0.123 - than the raw changes in reserves. Thus, to obtain a better proxy for Swiss intervention, changes in reserves should be deseasonalized. Consistent with the lack of regression evidence of seasonality for Germany and the United States, correlations for those cases change much less. Figure 5 compares the time series of rolling correlations for the Swiss data with and without the seasonal adjustment. The seasonal adjustment substantially raises the rolling correlation through most of the sample.

The overall correlation between Swiss reserves and intervention remains fairly low, despite the adjust-

\footnotetext{
${ }^{12}$ The author thanks Mathias Zurlinden of the Swiss National Bank for private communications regarding the role of monetary policy in generating seasonality in Swiss reserve changes.
} 


\section{Table 1}

\section{Summary Statistics on Central Bank Intervention and Changes in Reserves}

\begin{tabular}{|c|c|c|c|c|c|c|c|c|c|c|c|}
\hline & Date 1 & Date 2 & $\mu$ & $\sigma$ & $|\mu|$ & Min & Max & $\rho_{1}$ & $\rho_{2}$ & $\rho_{3}$ & $\rho_{4}$ \\
\hline $\operatorname{lntv}_{\text {US }}$ & 1973.04 & 1998.12 & -31.0 & 859.8 & 355.0 & -3413.2 & 6735.0 & .477 & 197 & .182 & .162 \\
\hline$\Delta \mathrm{FXR}_{\mathrm{US}}$ & 1973.04 & 1998.12 & 116.5 & 1275.4 & 740.6 & -7341.0 & 5667.0 & .209 & .154 & .131 & .080 \\
\hline Intv $_{\mathrm{G}}$ & 1976.01 & 1996.10 & -150.0 & 713.4 & 380.0 & -4895.4 & 1667.0 & .471 & .216 & .145 & .133 \\
\hline$\Delta \mathrm{FXR}_{\mathrm{G}}$ & 1976.01 & 1996.10 & 222.9 & 4968.8 & 1973.6 & -31629.0 & 53242.0 & -.241 & -.151 & .097 & -.022 \\
\hline Intv $_{\text {SW }}$ & 1986.01 & 1995.12 & -12.0 & 94.7 & 34.0 & -718.2 & 210.0 & .193 & .054 & .088 & .101 \\
\hline$\Delta \mathrm{FXR}_{\mathrm{SW}}$ & 1986.01 & 1995.12 & 143.5 & 1653.8 & 1199.0 & -4686.0 & 5996.0 & -.317 & -.311 & .435 & -.241 \\
\hline
\end{tabular}

NOTES: The columns of the table show the beginning and ending dates of samples, the means, standard deviations, mean absolute values, minimum and maximum for monthly intervention and changes in reserves. $\rho_{1}$ through $\rho_{4}$ denote the first four autocorrelation coefficients of each series. The variable names are as follows: Intv $\mathrm{US}_{\mathrm{S}}$ is in-market and withcustomer purchases; $\Delta \mathrm{FXR}_{\mathrm{US}}$ is the change in U.S. foreign exchange reserves; $\operatorname{Intv}_{\mathrm{G}}$ is German dollar purchases; $\Delta \mathrm{FXR} \mathrm{G}_{\mathrm{G}}$ is the change in German foreign exchange reserves; Intv ${ }_{S W}$ is Swiss franc (CHF) purchases of USD and DEM; and $\Delta F X R_{S W}{ }$ is the change in Swiss foreign exchange reserves. Variables are measured in millions of U.S. dollars.

\section{Table 2}

\section{Correlations Between Central Bank Intervention and Changes in Reserves}

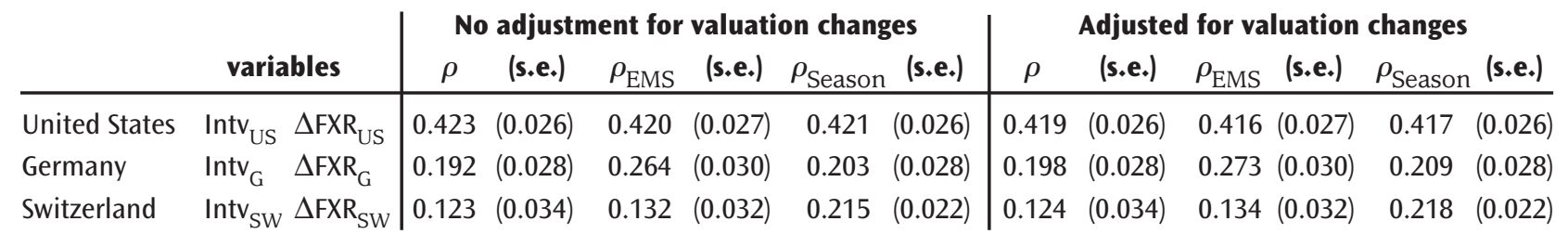

NOTES: The third column of the table (labeled $\rho$ ) shows the implied unconditional correlation between the variables listed in the second column and its standard error. The standard errors are computed assuming a first-order bivariate vector autoregression for each set of variables. The fourth column (labeled $\rho_{\text {EMS }}$ ) of the table shows the correlation between the variables with the months of ERM realignments removed while the fifth column (labeled $\rho_{\text {Season }}$ ) displays the correlations with deseasonalized reserve changes. The sixth through eighth columns of the table display the correlations after crudely adjusting the changes in reserves for valuation changes as described in the text. The U.S. sample runs from 1973:04 to 1998:12, the German sample from 1976:01 to 1996:10 and the Swiss sample from 1986:01 to 1995:12.

ment for seasonality. As was the case for Germany, a likely partial explanation for this low correlation is that foreign exchange swaps were a major instrument of Swiss monetary policy, causing fluctuations in Swiss reserves wholly unrelated to intervention. ${ }^{13}$

\section{Revaluation of Reserves}

In principle, one might adjust changes in reserves for valuation changes in the currency and asset composition of the reserve portfolio. For example, if the United States held its portfolio in six-month JPY-denominated bonds, one could approximate the change in the value of the portfolio from changes in the JPY/USD exchange rate and changes in Japanese six-month interest rates.

In practice, adjusting reserves for valuation changes is very difficult. Countries do not typically

\footnotetext{
${ }^{13}$ The use of foreign exchange in the conduct of Swiss monetary policy is discussed by the Swiss National Bank at < http://www.snb.ch/el geldpolitik/geldpol.html > . The link was current as of March 10, 2000
} 


\section{Figure 3}

\section{Normalized Cross Products of Intervention and Changes in Reserves}
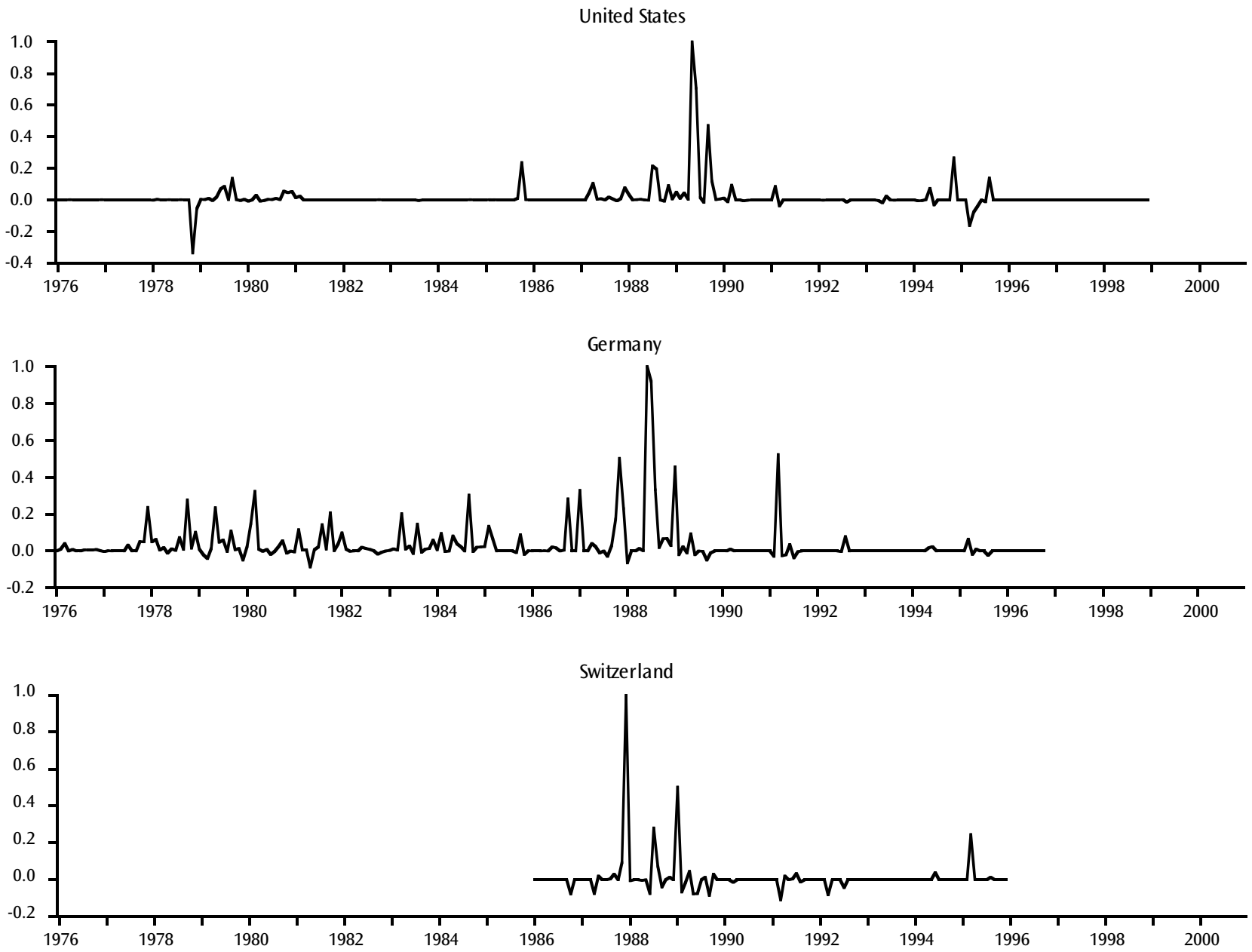

Notes: The figure shows the normalized time series of the product of intervention and changes in foreign exchange reserves. The products have been normalized by dividing by the largest value in each series.

report the currency and asset composition of their reserves portfolios and procedures for revaluing reserves vary from country to country. For example, the Federal Reserve Bulletin publishes revalued U.S. reserves figures each quarter, and reports that those balances are marked to market monthly at end-of-month exchange rates (Federal Reserve Bulletin, December 1999). ${ }^{14}$ The Swiss National Bank values purchases of foreign exchange and interest receipts at the exchange rate of the transaction and also revalues its reserves annually at end-of-year exchange rates (Swiss National Bank 91st Annual Report, 1998). Before 1997, the Bundesbank valued reserves at historically low market exchange ratesto conservatively estimate their DEM value-but now values them on an average purchase cost basis (Deutsche Bundesbank Annual Report, 1997). Finally, the IMF uses end-of-month exchange rates to convert reserves reported by national monetary authorities in units of domestic currency to U.S. dollars and SDRs.

Table 4-reproduced from the Federal Reserve Bulletin of December 1999-illustrates the proce-

\footnotetext{
${ }^{14}$ Reserves reported in the Federal Reserve Bulletin do not correspond precisely to those reported to the IMF by the Treasury. The reasons for this are not clear.
} 
Figure 4

\section{Four-Year Rolling Correlations Between German Official Intervention and Changes in Reserves Adjusted for ERM Realignments}

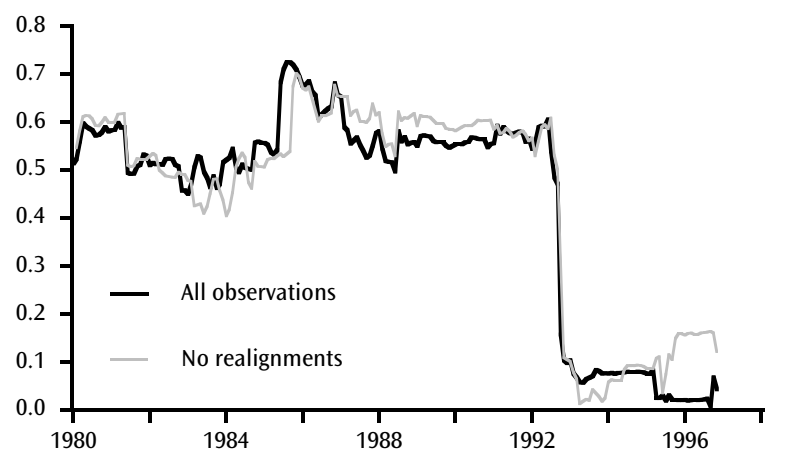

Notes: The panel compares 48-month rolling correlations between dollar intervention and changes in reserves for Germany, with and without months of ERM realignments.

\section{Table 3}

Coefficients on Seasonal Indicator Variables for Changes in Swiss Reserves

\begin{tabular}{lrr} 
& \multicolumn{1}{c}{ b } & (s.e.) \\
\hline January & -2599.7 & $(157.2)$ \\
February & -29.6 & $(160.3)$ \\
March & 630.4 & $(160.3)$ \\
April & -955.8 & $(157.2)$ \\
May & 354.7 & $(157.2)$ \\
June & 993.5 & $(157.2)$ \\
July & -993.6 & $(157.2)$ \\
August & 203.2 & $(157.2)$ \\
September & 800.0 & $(157.2)$ \\
October & -562.4 & $(157.2)$ \\
November & 579.6 & $(157.2)$ \\
December & 2810.2 & $(157.2)$
\end{tabular}

NOTES: The $2^{\text {nd }}$ and $3^{\text {rd }}$ columns display coefficients and standard errors from a regression of changes in Swiss foreign exchange reserves ( $\Delta$ FXR$\mathrm{sw}$ ) on a full set of seasonal indicator variables over the full sample available, 1973:4 to $1999: 1$

dures for revaluing U.S. reserves. The first line of Table 4, for example, shows that the Federal Reserve
System Open Market Account (SOMA) held \$6.944 billion worth of euros on June 30, 1999. ${ }^{15}$ Over the next three months, this account earned \$53 million in interest income and increased in value by $\$ 225$ million as a result of the appreciation of the euro over the period, increasing the value of this account to $\$ 7.222$ billion. Although there were no purchases or sales during this period, reserves changed substantially.

A very crude attempt at compensating for valuation changes can be made under some assumptions about the currency composition and maturity of foreign exchange reserves. We will assume that all foreign exchange reserves are held in dollars and earn the 3-month Treasury bill yield. These assumptions seem as reasonable as any other simple assumptions, given that most foreign exchange reserves are denominated in dollars - see the boxed insert on the Size and Composition of Currency Reservesand held in highly liquid, short-term assets. But any such assumptions are clumsy approximations. Most obviously, the United States does not-by definition-hold foreign exchange reserves in the form of dollars. But under these assumptions, we can adjust the changes in reserves for estimated valuation changes. The right-hand columns of Table 2 show that adjustment for estimated valuation changes makes only the most marginal improvement in correlations among changes in reserves and measures of intervention. The German correlation that excludes realignments $\left(\rho_{\mathrm{EMS}}\right)$ rises from 0.264 to 0.273 with valuation changes while the Swiss deseasonalized correlation $\left(\rho_{\text {Season }}\right)$ rises from 0.215 to 0.218 . U.S. correlations fall by 0.004 .

\section{CONCLUSION}

Because of the scarcity of data on official foreign exchange intervention, researchers commonly have used monthly changes in international reserves to proxy for intervention. This article has explored the question of whether changes in reserves are good proxies for central bank intervention by examining some simple statistical measures. Changes in reserves are correlated positively with intervention activity, but may not be correlated strongly. The use

\footnotetext{
${ }^{15}$ Note that the foreign currency holdings of the United States are split between the accounts of the Federal Reserve System (SOMA) and those of the Treasury, the exchange stabilization fund. Normally, the Federal Reserve Bank of New York apportions half of intervention operations on the Treasury's books and half to the Federal Reserve's books.
} 


\section{Table 4}

\section{Foreign Currency Holdings of U.S. Monetary Authorities Based on Current Exchange Rates, 1999:Q3}

Millions of dollars

\begin{tabular}{|c|c|c|c|c|c|c|c|}
\hline Item & $\begin{array}{c}\text { Balance } \\
\text { June } 30,1999\end{array}$ & $\begin{array}{l}\text { Net } \\
\text { purchases } \\
\text { and sales }\end{array}$ & $\begin{array}{l}\text { Effect of } \\
\text { sales }^{2}\end{array}$ & $\begin{array}{l}\text { Investment } \\
\text { Income }\end{array}$ & $\begin{array}{c}\text { Currency } \\
\text { valuation } \\
\text { adjustments }^{3}\end{array}$ & $\begin{array}{l}\text { Interest } \\
\text { accrual (net) } \\
\text { and other }\end{array}$ & $\begin{array}{c}\text { Balance } \\
\text { Sept. 30, } \\
1999\end{array}$ \\
\hline \multicolumn{8}{|c|}{$\begin{array}{c}\text { FEDERAL RESERVE SYSTEM } \\
\text { OPEN MARKET ACCOUNT } \\
\text { (SOMA) }\end{array}$} \\
\hline $\begin{array}{l}\text { EMU euro } \\
\text { Japanese yen } \\
\text { Total }\end{array}$ & $\begin{array}{r}6,943.7 \\
7,786.9 \\
14,730.6\end{array}$ & $\begin{array}{l}0.0 \\
0.0 \\
0.0\end{array}$ & $\begin{array}{l}0.0 \\
0.0 \\
0.0\end{array}$ & $\begin{array}{r}53.0 \\
2.0 \\
55.0\end{array}$ & $\begin{array}{r}225.1 \\
1,043.0 \\
1,268.1\end{array}$ & $\begin{array}{l}0.0 \\
0.0 \\
0.0\end{array}$ & $\begin{array}{r}7,221.8 \\
8,831.9 \\
16,053.7\end{array}$ \\
\hline $\begin{array}{l}\text { Interest receivables } \\
\text { Other cash flow } \\
\quad \text { from investments }\end{array}$ & 68.4 & $\ldots$ & $\cdots$ & $\cdots$ & $\cdots$ & -17.3 & 51.1 \\
\hline Total & $14,799.0$ & 0.0 & 0.0 & 55.0 & $1,268.1$ & -3.9 & $16,118.2$ \\
\hline \multicolumn{8}{|c|}{$\begin{array}{l}\text { U.S. TREASURY EXCHANGE } \\
\text { STABILIZATION FUND (ESF) }\end{array}$} \\
\hline $\begin{array}{l}\text { EMU euro } \\
\text { Japanese yen } \\
\text { Total }\end{array}$ & $\begin{array}{r}6,944.6 \\
7,787.0 \\
14,731.6\end{array}$ & $\begin{array}{l}0.0 \\
0.0 \\
0.0\end{array}$ & $\begin{array}{l}0.0 \\
0.0 \\
0.0\end{array}$ & $\begin{array}{r}49.3 \\
2.0 \\
51.3\end{array}$ & $\begin{array}{r}225.2 \\
1,042.8 \\
1,268.0\end{array}$ & $\begin{array}{l}0.0 \\
0.0 \\
0.0\end{array}$ & $\begin{array}{r}7,219.1 \\
8,831.8 \\
16,050.9\end{array}$ \\
\hline $\begin{array}{l}\text { Interest receivables } \\
\text { Other cash flow } \\
\quad \text { from investments }{ }^{5}\end{array}$ & 45.5 & $\ldots$ & $\ldots$ & $\ldots$ & $\ldots$ & 20.7 & 66.2 \\
\hline Total & $14,777.1$ & 0.0 & 0.0 & 51.3 & $1,268.0$ & 34.0 & $16,130.4$ \\
\hline
\end{tabular}

NOTE: Components may not sum to totals because of rounding.

${ }^{1}$ Purchases and sales for the purpose of this table include foreign currency sales and purchases related to official activity, swap drawings and repayments, and warehousing.

${ }^{2}$ This figure is calculated using marked-to-market exchange rates: It represents the difference between the sale exchange rate and the most recent revaluation exchange rate.

${ }^{3}$ Foreign currency balances are marked-to-market monthly at month-end exchange rates.

${ }^{4}$ Interest receivables for the ESF are revalued at month-end exchange rates. Interest receivables for the Federal Reserve System are carried at average cost of acquisition and are not marked to market until interest is paid. Interest receivables for the Federal Reserve System are net of unearned interest collected.

${ }^{5}$ Values for cash flow differences from payment and collection of funds between quarters.

... Not applicable.

\section{Source: Federal Reserve Bulletin}

of foreign exchange instruments for domestic monetary policy by Germany and Switzerland might significantly detract from the correlation. It is difficult to say whether changes in reserves are an adequate proxy for intervention because the answer to that question may depend on the issue being researched.
Filtering the reserves data to compensate for known features, like seasonality and ERM realignments, can increase the correlation of changes in reserves with intervention, making it a better proxy. After filtering out months of ERM realignments and crudely adjusting for valuation changes, the correla- 
tion between German dollar intervention and changes in foreign exchange reserves is 0.273 . Seasonally adjusting Swiss foreign exchange reserves and approximating valuation changes raises the correlation with Swiss franc intervention to 0.218. No adjustments to U.S. foreign exchange reserves data improve the correlation of 0.423 with in-market and with-customer intervention. Further research on how well changes in reserves proxy for intervention might compare directly the results of intervention studies using each kind of data.

In addition to removing seasonal factors and unusual periods like ERM realignments, other items for which one might adjust reserves include known government purchases out of reserves, repayment of foreign currency-denominated debt, and transactions like allocation of SDRs. To compensate for valuation changes to reserves would require knowledge of the currency and asset composition of each country's international reserves and the institutional procedures for revaluation. These adjustments would be difficult and time-consuming.

\section{REFERENCES}

Adams, Donald B., and Dale W. Henderson. "Definition and Measurement of Exchange Market Intervention," Staff Studies No. 126, Board of Governors of the Federal Reserve System, September 1983.

Almekinders, Geert J. "The Political Economy Of Central Bank Intervention,” Public Choice (July 1996), pp. 127-46.

Batten, Dallas S. “Central Banks' Demand for Foreign Exchange Reserves Under Fixed and Floating Exchange Rates," this Review (March 1982), pp. 20-30.

, Michael P. Blackwell, In-Su Kim, Simon E. Nocera, and Yuzuru Ozeki. "The Conduct of Monetary Policy in the Major Industrial Countries: Instruments and Operating Procedures," Occasional Paper No. 70, International Monetary Fund, July 1990.

Ben-Bassat, Avraham, and Daniel Gottlieb. "On the Effect of Opportunity Cost on International Reserve Holdings," Review of Economics and Statistics (May 1992a), pp. 329-32. and "Optimal International Reserves and Sovereign Risk," Journal of International Economics (November 1992b), pp. 345-62.

Bhattacharya, Utpal, and Paul A. Weller. "The Advantage to Hiding One's Hand: Speculation and Central Bank Intervention in the Foreign Exchange Market," Journal of Monetary Economics (July 1997), pp. 251-77.

Blinder, Alan S. "The Role of the Dollar as an International Currency," Eastern Economic Journal (Spring 1996), pp. 127-36.

\section{Figure 5}

\section{Fou r-Year Rolling Correlations Between Swiss Official Intervention and Seasonally Adjusted Changes in Reserves}

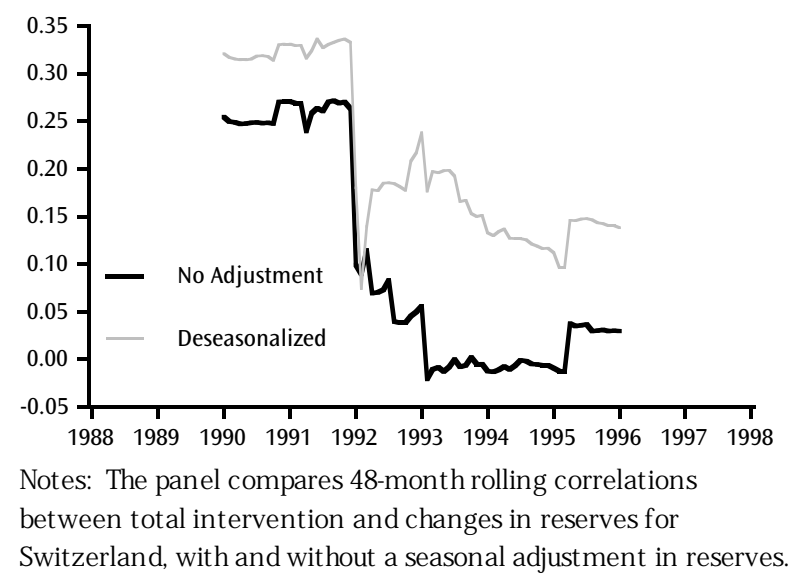

Board of Governors of the Federal Reserve System. "Foreign Currency Holdings of U.S. Monetary Authorities Based on Current Exchange Rates," Federal Reserve Bulletin (December 1999), p. 812.

Deutsche Bundesbank "Foreign Trade and Payments Influenced by Cyclical Weakness and Exchange Rate Turbulence," Annual Report (1993), pp. 45-55.

. "Valuation of Monetary Reserves,"

Annual Report (1997), pp. 60-69.

Economist. "Will the Buck Stop Here?" (November 12, 1994), p. 88.

Edison, Hali J. "The Effectiveness of Central-Bank Intervention: A Survey of the Literature After 1982," Special Papers in International Economics No. 18, Department of Economics, Princeton University, 1993.

Frankel, Jeffrey A. "Still the Lingua Franca: The Exaggerated Death of the Dollar," Foreign Affairs (July/August 1995), pp. 9-16.

Gartner, Manfred. "Intervention Policy under Floating Exchange Rates: An Analysis of the Swiss Case," Economica (November 1987), pp. 439-53.

"Foreign-Exchange Markets and Central-Bank Intervention," in Markets and Politicians: Politicized Economic Choice, Studies in Public Choice, Arye L. Hillman, ed., Kluwer Academic, 1991, pp. 319-38. 
Goodhart, Charles A. E., and Thomas Hesse. "Central Bank Forex Intervention Assessed in Continuous Time," Journal of International Money and Finance (August 1993), pp. 368-89.

Grubel, Herbert G. "The Demand For International Reserves: A Critical Review Of The Literature," Journal of Economic Literature (December 1971), pp. 1148-66.

Humpage, Owen. "Institutional Aspects of U.S. Intervention," Economic Review, Federal Reserve Bank of Cleveland (1994:1), pp. 2-19.

"U.S. Intervention: Assessing the Probability of Success," Journal of Money, Credit and Banking (November 1999), pp. 731-47.

Kaminsky, Graciela L., and Karen K. Lewis. "Does Foreign Exchange Intervention Signal Future Monetary Policy?” Journal of Monetary Economics (April 1996), pp. 285-312.

Kearney, Colm, and Ronald MacDonald. "Intervention and Sterilisation under Floating Exchange Rates: The UK 19731983," European Economic Review (April 1986), pp. 345-64.

Klein, Michael W. "The Accuracy of Reports of Foreign Exchange Intervention," Journal of International Money and Finance (December 1993), pp. 644-53.

Lewis, Karen K. "Are Foreign Exchange Intervention and Monetary Policy Related, and Does It Really Matter?" Journal of Business (April 1995), pp. 185-214.

Lizondo, Jose Saul, and Donald J. Mathieson. "The Stability Of The Demand For International Reserves," Journal of International Money and Finance (September 1987), pp. 251-82.

Loopesko, Bonnie E. "Relationships among Exchange Rates, Intervention, and Interest Rates: An Empirical Investigation," Journal of International Money and Finance (December 1984), pp. 257-77.

Mastropasqua, Cristina, Stefano Micossi, and Roberto Rinaldi. "Interventions, Sterilization and Monetary Policy in European Monetary System Countries, 1979-1987," in The European Monetary System: Proceedings of a Conference Organised by the Banca d' Italia, STEP, and $C E P R$, Francesco Giavazzi, Stefano Micossi, and Marcus Miller, eds., Cambridge University Press, 1988, pp. 252-87.

Neely, Christopher J. “Technical Analysis and the Profitability of U.S. Foreign Exchange Intervention," this Review, (July/August 1998), pp. 3-17. and Paul Weller. "Technical Analysis and Central Bank Intervention,” Federal Reserve Bank of St. Louis Working Paper 97-002C, February 2000.

Neumann, Manfred J.M., and Jurgen von Hagen. "Germany," in Monetary Policy in Developed Economies: Handbook of Comparative Economic Policies, Michele Fratianni and Dominik Salvatore, eds., Greenwood Press, 1993, pp. 299334.
Obstfeld, Maurice. "Exchange Rates, Inflation, and the Sterilization Problem: Germany, 1975-1981," European Economic Review (March/April 1983), pp. 161-89.

Peiers, Bettina. "Informed Traders, Intervention, and Price Leadership: A Deeper View of the Microstructure of the Foreign Exchange Market," Journal of Finance (September 1997), pp. 1589-614.

Roberts, Paul C. "The Inevitable Decline of a Reserve Currency," Wall Street Journal, March 16, 1995.

Swiss National Bank "Accounting and Valuation Principles," Swiss National Bank 91st Annual Report (1998), pp. 76-77.

Szakmary, Andrew C., and Ike Mathur. "Central Bank Intervention and Trading Rule Profits in Foreign Exchange Markets," Journal of International Money and Finance (August 1997), pp. 513-35.

Takagi, Shinji. "Foreign Exchange Market Intervention and Domestic Monetary Control in Japan, 1973-89," Japan and the World Economy (June 1991), pp. 147-80.

Taylor, Dean. "The Mismanaged Float: Official Intervention by the Industrialized Countries," in The International Monetary System: Choices for the Future, Michael B. Connolly, ed., Praeger Publishers, 1982a, pp. 49-84.

"Official Intervention in the Foreign Exchange Market, or, Bet Against the Central Bank," Journal of Political Economy (April 1982b), pp. 356-68. 
RE V I E W

32 SEPTEMBER/OCTOBER 2000 